\title{
Changes of myocardial enzyme activities in atrial fibrillation
}

\author{
G. Csapó
}

From the Fourth Clinic of Medicine, Semmelweis University of Medicine, Budapest, Hungary; and the Surgical Department of National Institute of Cardiology, Budapest, Hungary

Cholinesterase and succinyldehydrogenase activity of surgically removed left atrial auricles from patients in atrial fibrillation and in sinus rhythm have been compared, using histochemical methods. Higher cholinesterase and lower succinyldehydrogenase activity has been found in atrial fibrillation than in sinus rhythm. The pulmonary capillary mean pressure of patients with atrial fibrillation and sinus rhythm have been also compared. There was no significant difference between the two groups. On the basis of the reported examinations, it is not possible to decide whether the changes in enzyme activities are the cause or the result of atrial fibrillation.

Studies on the histochemical structure and metabolism of various parts of the heart muscle have shown the existing basic differences in the intermediary metabolism of the conductive system of the heart and of the working muscle mass, respectively. The oxygen uptake of the conductive system is lower, similar to the succinyldehydrogenase activity, while the glycogen concentration is higher than that of the working musculature (Schiebler, Stark, and Caesar, 1956; Isaacson and Boucek, I968; Opie, 1969). In contrast to the oxidative metabolism of the working muscles, that of the conductive system is characterized by anaerobic glycolysis, and this difference becomes more obvious as we go up the scale from lower to higher stimulatory centres. For this reason the resistance and tolerance of specific musculature to anoxia are much greater than those of the working muscles (Trautwein, Gottstein, and Dudel, 1954; Trautwein, 1963; Opie, 1969): thus the function of stimulation and conduction remains unaffected for longer in hypoxia. The sinus node is called the 'pars ultimum moriens cordis'.

The acetylcholinesterase activity of these tissues is also different: activity is higher in the conductive system in contrast with lower activity in working musculature (Burn, 1953; Carbonell, 1956; Dumont, 1957; Schiebler, 196I ; Harden, Mackenzie, and Ledingham, 1963; Müller and Pearse, 1965; Isaacson and Boucek, 1968; Opie, 1969). Cholinesterase activity is high in the early embryonal myo-

Received I March 1970. cardial tissues. During ontogenesis, as the enzyme activity characteristic of oxidative metabolism increases, the cholinesterase activity decreases in the respective parts of the heart musculature (Rawlinson, I931 ; DeHaan, 1961).

These histochemical and ontogenetic characteristics led us to the following hypothesis. According to Nachmansohn (I962) the acetylcholine-cholinesterase system is regarded as the specific chemical structure to be found in each zoological species and able to produce action potentials with propagation in the form of impulses. The necessary energy to supply this system is provided with the aid of anaerobic metabolism by the specific musculature (Opie, 1969). It might be assumed that the origin of some arrhythmias lies in the pathological shift of the metabolism and of the acetylcholine-cholinesterase system. The development of ectopic foci producing stimuli or the formation of circus movement (re-entry and micro-re-entry mechanism) are possible mechanisms of arrhythmias. The function of these foci and pathways is similar to that of the normal conductive system. It seems plausible that similarity in the function involves similar histochemical processes. It is to be expected that in these cases of arrhythmias high cholinesterase activity and increased rate of anaerobic metabolism - normally present only in the conductive system should be demonstrable in the working muscles as well.

As a first step to test the value of this hypothesis, cholinesterase and succinyldehydro- 
genase activities were determined in the excised left atrial auricles of patients with sinus rhythm and atrial fibrillation, who had been operated on for valvular and congenital heart disease.

\section{Material and methods}

The left atrial auricle excised during operation was bisected immediately after its removal. One piece of it was cooled to $0^{\circ} \mathrm{C}$., the other was fixed in 4 per cent formalin solution containing $\mathrm{I}$ per cent $\mathrm{CaCl}_{2}$ for 5 hours. Succinyldehydrogenase activity was estimated in the frozen part in freshly frozen slides prepared in the cryostat of Linde. Incubation of $20 \mu$ thick slides was performed at $37^{\circ} \mathrm{C}$. for 30 minutes, according to the method of Pearse (1960). The incubation solution contained nitro BT. Succinyldehydrogenase activity was reflected by the purple coloured reaction product at the sites of the mitrochondria. Cholinesterase activity was estimated in $\mathrm{CaCl}_{2}$-formalin solution fixed muscle tissue (Karnovsky and Roots, 1964). The fixed material was dissected with freezing microtome and the $20 \mu$ thick slides were placed in the incubating solution for 2 hours at $37^{\circ} \mathrm{C}$. The slides were covered with glycerol. Acetylthiocholiniodide was the substrate. The endproduct of the reaction was a very finely distributed reddish-brown sediment covering the whole of the muscle fibres (Fig.). The nuclei of the muscle fibres were always negative.

\section{Results}

The cholinesterase and succinyldehydrogenase activities of the left atrial auricles excised during operation on 48 patients with valvular and congenital heart disease have been estimated. Forty-one patients underwent mitral commissurotomy, and implantation of an artificial mitral valve was performed in three others, one patient receiving heterotransplantation of the aortic valve. Two patients were operated on because of septal defect and one other because of aortic coarctation. The mean age of the patients was 34 (17-52) years; there were 36 women and 12 men. The valvular disease was of rheumatic origin in each case. Seventeen patients had atrial fibrillation; in three, the arrhythmia consisted of supraventricular extrasystoles (Table). In all these cases succinyldehydrogenase activity was much reduced while the activity of cholinesterase was significantly increased. The sites with higher cholinesterase activity showed a patchy distribution (Fig.). In 26 of 28 patients operated on in sinus rhythm the cholinesterase activity of the auricle was normal. In two patients with sinus rhythm, cholinesterase activity was raised and succinyldehydrogenase activity was decreased. In one of the two patients there was cerebral and right lower extremity embolism which was possibly caused by paroxysmal atrial fibrillation. The pulmonary capillary pressures as measured during catheterization before operation in our patients in sinus rhythm or atrial fibrillation were also compared. There was no significant difference between the two groups: the mean pulmonary capillary pressure was $32.6 \mathrm{~mm}$. $\mathrm{Hg}$ in patients with sinus rhythm, and in those with arrhythmias this amounted to $30.7 \mathrm{~mm}$. $\mathrm{Hg}$. The same relation between groups with high and normal cholinesterase activity was $31 \cdot 6: 30 \cdot 9 \mathrm{~mm}$. $\mathrm{Hg}$.

\section{Discussion}

Several studies discuss the role of the acetylcholine-cholinesterase system in the physiology of stimulation and on the genesis of pathological stimuli. The theory of Nachmansohn (1962) has already been cited, together with studies proving that the cholinesterase

FIG. (a) Normal (Case II), and (b) increased (Case 28) cholinesterase activity of the left atrial auricle (Karnovsky and Roots, 1964). ( $\times$ 250.)

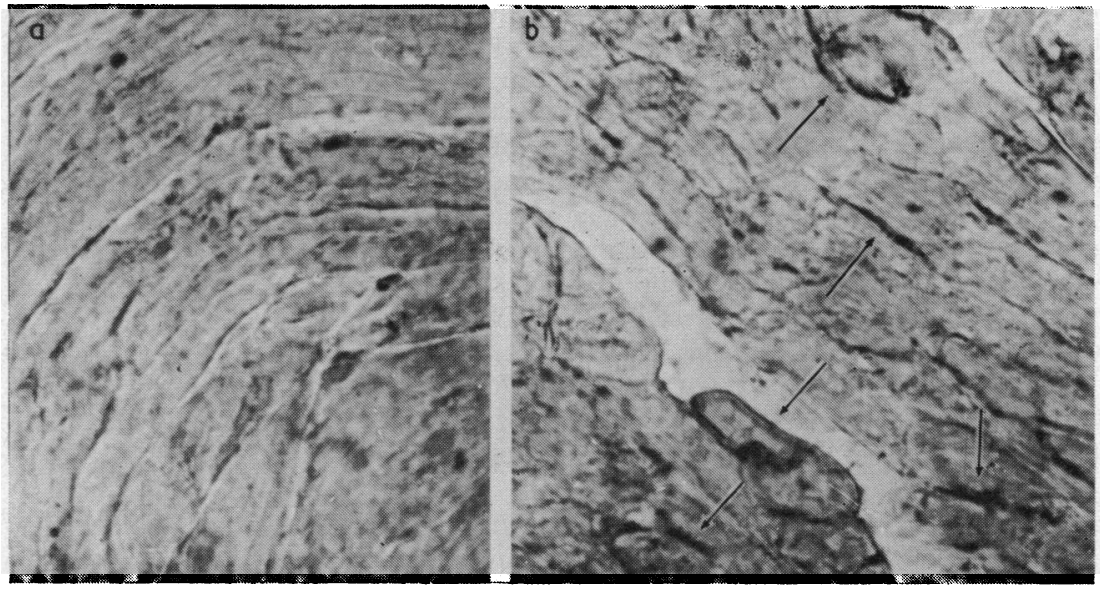


TABLE Myocardial enzyme activities and pulmonary capillary mean pressure of patients in sinus rhythm and atrial fibrillation

\begin{tabular}{|c|c|c|c|c|c|c|c|c|}
\hline $\begin{array}{l}\text { Case } \\
\text { No. }\end{array}$ & $\begin{array}{l}\text { Age } \\
(y r .)\end{array}$ & Sex & \multicolumn{2}{|c|}{ Diagnosis } & Rhythm & $\begin{array}{l}\text { Cholin- } \\
\text { esterase } \\
\text { activity }\end{array}$ & $\begin{array}{l}\text { Succinyl- } \\
\text { dehydro- } \\
\text { genase } \\
\text { activity }\end{array}$ & $\begin{array}{l}\text { Pulmonary } \\
\text { capillary } \\
\text { mean } \\
\text { pressure } \\
(\mathrm{mm} . \mathrm{Hg})\end{array}$ \\
\hline $\mathbf{I}$ & 26 & $\mathbf{F}$ & \multicolumn{2}{|c|}{ Mitral stenosis } & SR & \multirow{8}{*}{$\begin{array}{l}\text { Normal } \\
\uparrow \\
\text { Normal } \\
\text { Normal } \\
\text { Normal } \\
\uparrow \uparrow \uparrow \\
\text { Normal } \\
\uparrow \uparrow\end{array}$} & \multirow{8}{*}{$\begin{array}{l}\text { Normal } \\
\downarrow \\
\text { Normal } \\
\text { Normal } \\
\text { Normal } \\
\downarrow \downarrow \\
\text { Normal } \\
\downarrow \downarrow\end{array}$} & 24 \\
\hline 2 & 43 & $\mathbf{F}$ & 川 & و & AF & & & - \\
\hline 3 & 28 & $\mathbf{F}$ & & " & SR & & & 42 \\
\hline 4 & 28 & $\mathbf{F}$ & Artifi & 1 mitral incompet. & SR & & & - \\
\hline 5 & 42 & $\mathbf{M}$ & Mitra & tenosis and incompet. & SR & & & - \\
\hline 6 & 48 & $\mathbf{F}$ & Mitra & tenosis & AF & & & 32 \\
\hline 7 & 23 & $\mathbf{F}$ & 川 & , & SR & & & 40 \\
\hline 8 & 34 & $\mathbf{F}$ & \multicolumn{2}{|c|}{$\begin{array}{l}\text { Mitral stenosis, cerebral and femoral } \\
\text { embolism }\end{array}$} & SR & & & 65 \\
\hline 9 & 45 & $\mathbf{M}$ & \multirow{3}{*}{\multicolumn{2}{|c|}{$\begin{array}{l}\text { Mitral stenosis } \\
\text { Mitral stenosis, cerebral embolism } \\
\text { Mitral stenosis }\end{array}$}} & AF & $\uparrow \uparrow \uparrow$ & $\downarrow \downarrow \downarrow$ & - \\
\hline 10 & 27 & $\mathbf{F}$ & & & Atr. ex. & $\uparrow$ & & 一 \\
\hline II & 30 & $\mathbf{F}$ & & & SR & Normal & Normal & 35 \\
\hline 12 & 30 & $\mathbf{M}$ & \multirow{3}{*}{\multicolumn{2}{|c|}{$\begin{array}{l}\text { Aortic incompet. } \\
\text { Mitral stenosis }\end{array}$}} & SR & $\uparrow$ & $\downarrow$ & 27 \\
\hline 13 & 24 & $\mathbf{M}$ & & & SR & Normal & Normal & - \\
\hline 14 & 43 & $\mathbf{M}$ & & & AF & $\uparrow$ & \multirow{3}{*}{$\begin{array}{l}\downarrow \\
\text { Normal } \\
\downarrow \downarrow\end{array}$} & 24 \\
\hline 15 & 33 & $\mathbf{F}$ & \multicolumn{2}{|c|}{ " } & SR & \multirow{3}{*}{$\begin{array}{l}\text { Normal } \\
\uparrow \uparrow \\
\text { Normal }\end{array}$} & & 35 \\
\hline 16 & 39 & $\mathbf{F}$ & 川 & " & AF & & & 70 \\
\hline 17 & 22 & $\mathbf{F}$ & " & " & SR & & Normal & - \\
\hline 18 & 36 & $\mathbf{M}$ & & " & SR & Normal & Normal & 38 \\
\hline 19 & 31 & $\mathbf{F}$ & פ & " & SR & Normal & Normal & - \\
\hline 20 & 52 & $\mathbf{F}$ & , & "9 & AF & $\uparrow \uparrow$ & $\downarrow \downarrow$ & 12 \\
\hline $2 \mathbf{I}$ & 38 & $\mathbf{M}$ & , & " & SR & Normal & Normal & - \\
\hline 22 & 24 & $\mathbf{F}$ & 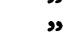 & " - & SR & Normal & Normal & - \\
\hline 23 & 45 & $\mathbf{M}$ & " & و & AF & $\uparrow \uparrow \uparrow$ & $\downarrow \downarrow \downarrow$ & 25 \\
\hline 24 & 40 & $\mathbf{M}$ & 川 & " & AF & $\uparrow \uparrow$ & $\downarrow \downarrow$ & - \\
\hline 25 & 40 & $\mathbf{F}$ & \% & " & SR & Normal & $\downarrow$ & 18 \\
\hline 26 & 48 & $\mathbf{F}$ & ” & " & AF & $\uparrow \uparrow$ & $\downarrow \downarrow$ & - \\
\hline 27 & 23 & $\mathbf{F}$ & , & " & SR & Normal & Normal & 55 \\
\hline 28 & 26 & $\mathbf{F}$ & , & " & AF & $\uparrow \uparrow$ & $\downarrow \downarrow$ & 24 \\
\hline 29 & 25 & $\mathbf{F}$ & و, & " & SR & Normal & Normal & 25 \\
\hline 30 & 49 & $\mathbf{F}$ & " & 》 & SR & Normal & Normal & 17 \\
\hline 31 & 45 & $\mathbf{F}$ & " & و & AF & $\uparrow \uparrow \uparrow$ & $\downarrow \downarrow$ & 46 \\
\hline 32 & 23 & $\mathbf{F}$ & & " & AF & $\uparrow \uparrow$ & $\downarrow$ & - \\
\hline 33 & 28 & $\mathbf{F}$ & Atria & ptal defect & SR & Normal & Normal & - \\
\hline 34 & $3 \mathbf{I}$ & $\mathbf{F}$ & Mitr & tenosis & SR & Normal & Normal & 20 \\
\hline 35 & 30 & $\mathbf{F}$ & ” & 川 & Atr. ex. & & & 20 \\
\hline 36 & 39 & $\mathbf{F}$ & 川 & ” & SR & Normal & Normal & 38 \\
\hline 37 & 30 & $\mathbf{M}$ & & " & AF & & & 33 \\
\hline 38 & 17 & $\mathbf{F}$ & Coar & ion of aorta & SR & Normal & Normal & - \\
\hline 39 & 17 & $\mathbf{F}$ & Vent & and atrial septal defect & SR & Normal & Normal & 8 \\
\hline 40 & 46 & $\mathbf{M}$ & Mitr & tenosis & Atr. ex. & $\uparrow \uparrow$ & $\downarrow \downarrow$ & 27 \\
\hline 41 & 37 & $\mathbf{F}$ & " & " & SR & Normal & $\downarrow \downarrow$ & - \\
\hline 42 & 46 & $\mathbf{F}$ & ” & " & AF & $\uparrow \uparrow \uparrow$ & & 37 \\
\hline 43 & 43 & $\mathbf{F}$ & 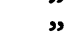 & " & AF & $\uparrow \uparrow$ & $\downarrow \downarrow \downarrow$ & 25 \\
\hline 44 & 30 & $\mathbf{F}$ & " & 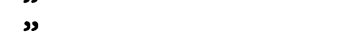 & SR & Normal & Normal & 40 \\
\hline 45 & 21 & $\mathbf{F}$ & " & " & AF & $\uparrow \uparrow$ & $\downarrow \downarrow$ & 25 \\
\hline 46 & 23 & $\mathbf{M}$ & " & " & SR & Normal & Normal & 27 \\
\hline 47 & 49 & $\mathbf{F}$ & " & " & AF & $\uparrow \uparrow \uparrow$ & $\downarrow \downarrow \downarrow$ & 30 \\
\hline 48 & 33 & $\mathbf{F}$ & 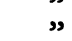 & " & SR & Normal & Normal & - \\
\hline
\end{tabular}

SR, sinus rhythm; AF, atrial fibrillation; Atr. ex., atrial extrasystole.

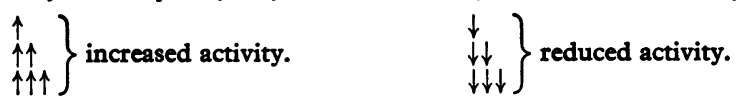

activity of the conductive system is higher, and its oxidative metabolism is lower than that of the working musculature. Bülbring and Burn (1949) found that the rate of the spontaneously working auricle of the rabbit was decreased concomitantly with the decrease in the amount of endogenous acetyl- choline. After spontaneous activity of the auricle stopped, pulsation was started again when acetylcholine was administered. Trautwein and Dudel (1958a, b), by studying the membrane potentials of the heart muscle fibres, confirmed these findings and put them on an electrophysiological basis. According 
to Szekeres et al. (Szekeres, 1954; Szekeres, Bánhidy, and Molnar, 1958; Szekeres and Papp, 1965) stimulation of the vagus or infusion of acetylcholine decreased the diastolic fibrillatory threshold, and these effects were more obvious in hypoxia. Burn (1953, 1957) proved that acetylcholine was synthetized even locally in the myocardium, and after reaching a given concentration it induced contraction. Burn, Williams, and Walker (1955) and Loomis and Krop (1955) described how ventricular fibrillation might be induced by intravenous administration or local application of acetylcholine. Development of fibrillation after extrasystole-producing pacemaker stimulation in the presence of acetylcholine has also been noted (Holland, Burn, and Schümann, 1957; Rand and Walker, 1958; West and Cox, 1960; Zacouto and Coraboeuf, 1964; Yamada et al., 1968; Csapó, 1971). Melnikova (1967) noted increased cholinesterase activity in the tissues of hearts with chronic myocardial hypertrophy. Peretz et al. (1965) assumed that changes in the cholinesterase activity might play a role in the genesis of arrhythmias accompanying myocardial infarction: the tissue $p \mathrm{H}$ falls due to local metabolic acidosis. The activity of the cholinesterase decreases because its optimal $p \mathrm{H}$ lies between 7.5 and 8.5 . In studying the common pharmacological features of the antiarrhythmic drugs, Burn (1956) stated that these inhibited acetylcholine.

In our present experiments the cholinesterase and succinyldehydrogenase activities of the left atrial auricle from patients in sinus rhythm and atrial fibrillation were compared. Much higher cholinesterase and much lower succinyldehydrogenase activities have been found in patients with atrial fibrillation than in those with sinus rhythm. It seems, therefore, as far as these two parameters are concerned, that in cases of atrial fibrillation the histochemical structure of the working musculature of the atrium approaches that of the conductive system: its anaerobic metabolism (reduced succinyldehydrogenase activity) and its cholinesterase activity are increased.

On the basis of our examinations, we are not able to decide if atrial fibrillation is followed or caused by enzyme changes, or whether higher cholinesterase activity is due to an increased acetylcholine content or not. In cases of atrial fibrillation enzyme activities were not detected, whereas in cases of sinus rhythm, values higher than normal were seen, and in two cases (Cases 24 and 4I) a reduced succinyldehydrogenase activity was found when cholinesterase activity was normal.
These findings lead us to suppose that the primary change might be a shift in the intermediary metabolism due to hypoxia. This may be followed by the imbalance of the acetylcholine-cholinesterase system and by the onset of arrhythmia. It is hoped that a solution will be found from the experiments now under way, including quantitative analyses of cholinesterase and glycogen content and measurements of the enzymes of glycolysis of atrial muscle.

\section{References}

Bülbring, E., and Burn, J. H. (1949). Action of acetylcholine on rabbit auricles in relation to acetylcholine synthesis. Fournal of Physiology, 108, 508.

Burn, J. H. (1953). Acetylcholine and the heart beat. Lancet, $\mathrm{I}, \mathrm{I} 16 \mathrm{I}$.

- (1956). Functions of Autonomic Transmitters. Williams and Wilkins, Baltimore.

- (1957). Acetylcholine and cardiac fibrillation. British Medical Bulletin, 13, I81.

- Williams, E. M. Vaughan, and Walker, J. M. (1955). The production of block and auricular fibrillation in the heart-lung preparation by inhibitors of cholinesterase. British Heart fournal, 17, 431 .

Carbonell, L. M. (1956). Esterases of the conductive system of the heart. fournal of Histochemistry and Cytochemistry, 4,87 .

Csapó, G. (I97I). The role of ventricular premature beats in the initiation and the termination of atrial arrhythmias. British Heart fournal. In the press.

DeHaan, R. L. (1961). Differentiation of the atrioventricular conducting system of the heart. Circulation, $24,458$.

Dumont, L. (1957). Localisation histochimique d' acétylcholinesterase dans les régions nodales du coeur de mammifère. Annales d'Histochimie, 2, 19.

Harden, K., Mackenzie, J. L., and Ledingham, J. M. (1963). Spontaneous reversion of ventricular fibrillation. Lancet, 2, I 140.

Holland, W. C., Burn, J. H., and Schümann, H. J. (1957). Production of auricular fibrillation by electrical stimulation of isolated rabbit auricles in the presence of acetylcholine (Abstract). Fournal of Pharmacology and Experimental Therapeutics, II9, I53.

Isaacson, R., and Boucek, R. J. (1968). The atrioventricular conduction tissue of the dog. American Heart fournal, 75, 206.

Karnovsky, M. J., and Roots, L. (1964). A 'directcoloring' thiocholine method for cholinesterases. Fournal of Histochemistry and Cytochemistry, 12, 219.

Loomis, T. A., and Krop, S. (1955). Auricular fibrillation induced and maintained in animals by acetylcholine or vagal stimulation. (In Russian; English summary.) Circulation Research, 3, 390.

Melnikova, A. P. (1967). Histochemistry of cholinesterase of the myocardium in its hypertrophy. Arkhiv patologil, 29, No. I, p. 44.

Müller, E., and Pearse, A. G. E. (1965). Localization of monoamine oxidase in mammalian and reptilian heart. British Heart fournal, 27, I 16.

Nachmansohn, D. (1962). Chemical factors controlling nerve activity. Science, 134, 1962.

Opie, L. H. (1969). Metabolism of the heart in health and disease. Part II. American Heart fournal, 77, roo. 
Pearse, A. G. E. (1960). Histochemistry, Theoretical and Applied, and ed. Churchill, London.

Peretz, D. I., Scott, H. M., Duff, J., Dossetor, J. B., MacLean, L. D., and McGregor, M. (1965). The significance of lacticacidemia in the shock syndrome. Annals of the New York Academy of Sciences, 119, 1133.

Rand, M. J., and Walker, J. M. (1958). A comparison of antifibrillatory drugs in the heart-lung preparation. British fournal of Pharmacolocy and Chemotherapy, $13,107$.

Rawlinson, H. E. (1931). The later development of the sinus venosus and the relation of the sino-atrial node to it, in the calf heart. Anatomical Record, 49, 89.

Schiebler, T. H. (196I). Histochemische Untersuchungen am Reizleitungssystem tierischer Herzen. Naturwissenshaften, 48, 502.

—, Stark, M., and Caesar, R. (1956). Die Stoffwechselsituation des Reizleitungssystems. Klinische Wochenschrift, 34, I81.

Szekeres, L. (1954). Einfluss von Hypoxie auf die Vagus- und Azetylcholinempfindlichkeit des Säugetierherzens. Acta physiologica Academiae Scientiarum Hungariae, 6, 109.

—, Bánhidy, J., and Molnar, M. (1958). Die Wirkung des Acetylcholins auf den Stoffwechsel des normalen und des hypoxischen Herzmuskels. Arzneimittel-Forschung, 8, 358.

- and Papp, J. (1965). The effect of vagal stimulation and acetylcholine on the susceptibility to fibrillation of the mammalian heart at different body temperatures. Acta physiologica Academiae Scientiarum Hungaricae, 26, 277.

Trautwein, W. (1963). Generation and conduction of impulses in the heart as affected by drugs. Pharmacological Reviews, 15, 277.

- , and Dudel, J. (1958a). Zum Mechanismus der Membranwirkung des Acetylcholin an der Herzmuskelfaser. Pflügers Archiv für die gesamte Physiologie des Menschen und der Tiere, 266, 324.

$\longrightarrow$, and $-(1958 \mathrm{~b})$. Hemmende und 'erregende' Wirkungen des Acetylcholin am Warmblüterherzen. Zur Frage der spontanen Erregungsbildung. Pflügers Archiv für die gesamte Physiologie des Menschen und der Tiere, 266, 653.

- Gottstein, U., and Dudel, J. (1954). Der Aktionsstrom der Myokardfaser im Sauerstoffmangel. Pflügers Archiv für die gesamte Physiologie des Menschen und der Tiere, 260, 40.

West, T. C., and Cox, A. R. (1960). Single fiber recording during the production and control of flutter in the isolated atrium of the rabbit. Fournal of Pharmacology and Experimental Therapeutics, 130, 303.

Yamada, K., Okajima, M., Hori, K., Fujino, T., Muraki, H., Hishida, H., and Kobayaski, T. (1968). On the genesis of the absolute ventricular arrhythmia associated with atrial fibrillation. Circulation Research, 22, 707.

Zacouto, F., and Coraboeuf, E. (1964). Wirkungsmechanismen der Elektrokardiotherapie. Verhandlungen der Deutschen Gesellschaft für Krieslaufforschung, 30, 249. 